\title{
Exploring the antimicrobial potential of Pardosa brevivulva silk
}

\author{
Nagnath Nandu Phartale, Tukaram Angadrao Kadam, Hemlata J. Bhosale, Mahesh A. Karale and \\ Gyananath Garimella*
}

\begin{abstract}
Background: Pardosa is the genus of wolf spiders erected by C. L. Koch, 1847, currently represented by 549 species worldwide and 40 species from India.

Results: The present investigation deals with the first report of Pardosa brevivulva (Tanaka, Bulletin of the Biogeographical Society of Japan 31:21-24, 1975) in India from the mango and soybean fields of Latur District, Maharashtra. The species level identification was carried out on the basis of morphological characters and 18S rRNA gene sequencing. The silk of Pardosa brevivulva (Tanaka, Bulletin of the Biogeographical Society of Japan 31:21-24, 1975) was tested for its antimicrobial potential against test microbes. The bioactive fraction of Pardosa brevivulva silk was characterized for antimicrobial compounds by FT-IR, ${ }^{13} \mathrm{C} \&{ }^{1} \mathrm{H} N M R$, and $C_{18}$ column RP-HPLC analysis. The silk was able to inhibit the growth of B. megaterium, S. typhi, K. pneumoniae, A. flavus, C. albicans, U. maydis, and A. solani.
\end{abstract}

Conclusion: It can be surmised from the present investigation that the Pardosa brevivulva silk has good antimicrobial potential with useful bactericidal and fungicidal properties.

Keywords: Spider silk, Antimicrobial activity, Pardosa brevivulva

\section{Background}

The family Lycosidae consists of 2421 species of spiders belonging to 124 genera which are known for the unique eye pattern and typical egg sac carrying behavior. Keswani, Hadole, and Rajoria (2012) reported 133 species belonging to 19 genera belonging to family Lycosidae from India. Phartale, Kadam, and Gyananath (2016) reported Geolycosa charitonovi (Mcheidze, 1997) for the first time from India in the mango fields of Latur district. Pardosa is the genus of wolf spiders presently represented by 549 species worldwide (World Spider Catalogue, 2017) and 40 species from India (Keswani et al., 2012). Pardosa brevivulva was firstly reported by Tanaka (1975) from Japan. It is commonly found in Russia, China, Korea, and Japan. The present investigation is the first report of this species in India from the mango and soybean fields of Latur District, Maharashtra.

Spiders are equipped with nature's most wondrous material known as spider silk. It is of great interest

\footnotetext{
*Correspondence: gyananath52@gmail.com

School of Life Sciences, S. R. T. M. University, Nanded 431606, India
}

because of its extraordinary physical properties, such as strength and toughness. A total of 41,000 species of spiders reported to produce silk (Agnarsson, Kuntner, \& Blackledge, 2010). The spiders have utilized this material in prey capture, forcing its evolution to a high performance fiber. Orb-weaving spiders can produce up to seven different types of silk, and all these have different physical properties, which relate to their various functions (Andersen, 1970; Saravanan, 2006). The variations in properties are due to underlying differences in the protein making of these silks. As our understanding of spider silk has increased in the recent years, the spider silk is a highly desirable material for applications ranging from biomaterials to high-performance fibers for industrial applications. The most studied and best understood spider silks are the major ampullate silks from the Nephilidae family of orb weavers. These are considered to be the benchmark for synthetic silks in terms of structure and mechanical properties.

The remarkable properties associated with spider silks are yet to be explored. Considering the phenomenal interest in using the spider silk for various applications, 
an attempt is made here to characterize the spider silk for antimicrobial activity.

\section{Materials and methods Materials}

Genelute Mammalian Genomic DNA extraction kit was purchased from Sigma, the reagents used for PCR amplification were procured from $\mathrm{GeNei}$, and the polymerase chain reaction (PCR) amplification was performed using Biometra thermal cycler (T-Personal 48). All other reagents were procured from Hi-Media, Mumbai.

\section{Collection and identification of spiders}

The spiders were collected early in the morning from soybean and mango fields of Bhada village, Tq. Ausa, Dist. Latur as per the procedure described by Coddington, Griswold, Silva, Penaranda, and Larcher (1991) and Toti, Coyle, and Miller (2000). The identification of spiders was carried on the basis of morphological characteristics. The species level identification was further confirmed by the $18 \mathrm{~S}$ rRNA gene sequencing.

\section{S rRNA gene sequencing}

DNA Extraction was carried out using Genelute Mammalian Genomic DNA extraction kit (Sigma, G1 N70-1KT). The DNA isolated from spider was subjected to polymerase chain reaction (PCR) amplification using Biometra thermal cycler (T-Personal 48). The PCR reaction mix contained $2.5 \mu \mathrm{l}$ of $10 \mathrm{X}$ buffer, $1 \mu \mathrm{l}$ of each forward and reverse primers with base sequence: $18 \mathrm{~s} 5 \mathrm{~F}$ (Forward)-CTGGTTGATYCTGCCAGT and 18s1100R (Reverse)-CTTCGAACCTCTGACTTTCG, $2.5 \mu \mathrm{l}$ of $2.5 \mathrm{mM}$ of each dNTP, 2.5 Units of Taq DNA polymerase, and $1 \mu \mathrm{l}$ Template DNA and $8.5 \mu \mathrm{l}$ nuclease-free water. The PCR amplification cycle consist of a cycle of $5 \mathrm{~min}$ at $94^{\circ} \mathrm{C}$; 35 cycles of $1 \mathrm{~min}$ at $94{ }^{\circ} \mathrm{C}, 1 \mathrm{~min}$ at $55^{\circ}$ $\mathrm{C}, 2 \mathrm{~min}$ at $72{ }^{\circ} \mathrm{C}$; and additionally 1 cycle of $7 \mathrm{~min}$ at $72{ }^{\circ} \mathrm{C}$. Gel electrophoresis was performed using 1.0\% agarose to analyze the size of amplified PCR product. The size obtained was approx. $1000 \mathrm{bp}$ for partial 18s rRNA region. The PCR product was purified using AxyPrep PCR Clean up kit (Axygen, AP-PCR-50). It was further sequenced using Applied Biosystems 3730xl DNA Analyzer USA and chromatogram was obtained. The DNA sequences were analyzed using online Nucleotide Basic Local Alignment Search Tool (BLASTn) facility of National Center for Biotechnology Information (NCBI). The BLAST results were used to find out evolutionary relationship of spider. Altogether, 20 sequences, including sample sequence, were used to generate phylogenetic tree. The tree was constructed in NCBI using neighbor joining method.

\section{Antimicrobial activity of silk \\ Collection of spider silk}

Spider silk was collected by running the sterile pipette through the web from soybean and mango fields of Bhada village, Tq. Ausa, Dist. Latur. This silk was employed for the assessment of antimicrobial activity.

\section{Silk solubilization}

The silk of $P$. brevivulva $(1.0 \mathrm{mg})$ was placed in sterile glass borosilicate test tubes and $10 \mathrm{ml}$ of different solvents like chloroform, formic acid, ethanol and methanol, water, and $1 \mathrm{~N} \mathrm{HCl}$ were added separately to test the solubility of silk.

\section{Test organisms}

Both gram-positive as well as gram-negative bacterial strains were used for the assessment of antibacterial activity. Bacillus megaterium (MTCC 2444) and Staphylococcus aureus (MTCC 96) were the gram-positive bacterial strains while Klebsiella pneumoniae (ATCC 15380), Pseudomonas aeruginosa (MTCC 2488), Proteus vulgaris (MTCC 1771), and Salmonella typhi (ATCC 23564) were the gram-negative bacterial strains used in the study. The selected test fungi were Aspergillus niger (MTCC 1781), Aspergillus flavus (MTCC 873), Candida albicans (MTCC 227), Ustilago maydis (MCIM 983), Alternaria solani (MCIM 887), and Mucor hiemalis (MCIM 873). Each bacterial species was inoculated in nutrient broth and fungal species in potato dextrose broth separately on orbital shaking incubator (REMI-24 $\mathrm{BL}$ ) for 24 to $48 \mathrm{~h}$.

\section{Antibacterial assay}

Silk extract of $P$. brevivulva was tested for antibacterial activity against six bacterial species such as $B$. megaterium, K. pneumoniae, P. aeruginosa, P. vulgaris, S. typhi, and $S$. aureus. The antibacterial activity was carried out by disc diffusion method. Nutrient agar plates were prepared and $100 \mu \mathrm{l}$ of the test microbe was pipetted onto the center of the plate and then spread around using the glass spreader. Disc loaded with silk sample was placed onto the surface of the agar. Then, the plates were placed in an incubator at $37 \pm 1{ }^{\circ} \mathrm{C}$ and left for around $24 \mathrm{~h}$. The result was recorded by measuring the diameter of zone of inhibition $(\mathrm{mm})$.

\section{Antifungal assay}

Silk extract of $P$. brevivulva was tested against six fungal species viz. A. niger, A. flavus, C. albicans, $U$. maydis, $A$. solani, and $M$. hiemalis. The antifungal activity was carried out by agar well diffusion method. Potato dextrose agar plates were prepared and after solidification, $100 \mu \mathrm{l}$ of the spore suspension was pipetted on to the center of the plate and then spread around using the glass 
Table 1 Measurements of legs of Pardosa brevivulva

\begin{tabular}{lllllll}
\hline Legs & Femur $(\mathrm{mm})$ & Patella $(\mathrm{mm})$ & Tibia $(\mathrm{mm})$ & Metatarsus $(\mathrm{mm})$ & Tarsus $(\mathrm{mm})$ & Total $(\mathrm{mm})$ \\
\hline I & 1.822 & 0.910 & 1.722 & 1.219 & 0.656 & 1.005 \\
II & 1.567 & 0.879 & 1.249 & 1.377 & 1.329 & 6.077 \\
III & 1.249 & 0.727 & 1.002 & 1.167 & 1.974 & 5.219 \\
\hline
\end{tabular}

spreader. The wells were made on agar plate by using cork borer. Then, $30 \mu \mathrm{l}$ of silk extract was introduced in the well. The plates were incubated at $28 \pm 1{ }^{\circ} \mathrm{C}$ for $24-$ $48 \mathrm{~h}$. The antifungal activity was evaluated by measuring the zone of inhibition ( $\mathrm{mm})$.

\section{Dialysis of silk samples}

The membrane dialysis of silk extract was performed as per the procedure described by Lombardi and Kaplan (1990). The silk extract was dialyzed against $1000 \mathrm{ml}$ of $10 \mathrm{mM}$ Tris- $\mathrm{HCl}$ buffer ( $\mathrm{pH} 7.0$ ) for $24 \mathrm{~h}$ and the samples were re-dissolved in dimethyl sulfoxide (DMSO) for further analysis.

\section{Antimicrobial activity of DMSO fraction of silk samples}

The antibacterial activity of $P$. brevivulva silk was confirmed by testing DMSO fraction of silk against B. megaterium, S. typhi, and K. pneumoniae by disc diffusion method. Streptomycin $(50 \mu \mathrm{g} / \mathrm{ml})$ was used as positive control and DMSO was used as negative control.

The DMSO fraction of $P$. brevivulva silk was also tested for the confirmation of its antifungal potential against $A$. niger, A. flavus, C. albicans, $U$. maydis, and $A$. solani by agar well diffusion method. Nystatin $(50 \mu \mathrm{g} /$ $\mathrm{ml}$ ) was used as positive control and DMSO was used as negative control.

\section{Estimation of protein content of DMSO fraction of silk samples}

The protein content of DMSO fraction of P. brevivulva silk was determined by the method as described by Bradford (1976) with Coomassie Brilliant Blue (G-250) dye using bovine serum albumin as the standard.

\section{Determination of minimum inhibitory concentration}

Minimum inhibitory concentration of DMSO fraction of Pardosa brevivulva silk was determined using Alamer Blue Assay (Rampersad, 2012; Yajko et al., 1995) for

Table 2 Measurements of eyes of Pardosa brevivulva

\begin{tabular}{lllll}
\hline Eyes & Radius $(\mathrm{mm})$ & Diameter $(\mathrm{mm})$ & Perimeter $(\mathrm{mm})$ & Area $\left(\mathrm{mm}^{2}\right)$ \\
\hline PLE & 0.052 & 0.104 & 0.327 & 0.009 \\
PME & 0.125 & 0.250 & 0.785 & 0.049 \\
ALE & 0.042 & 0.083 & 0.262 & 0.005 \\
AME & 0.063 & 0.125 & 0.393 & 0.012 \\
\hline
\end{tabular}

three different bacterial species (B. megaterium, S. typhi, and K. pneumoniae). The DMSO fraction of Pardosa brevivulva silk was also was tested for the determination of minimum inhibitory concentration against C. albicans and Aspergillus flavus. Each well of microtitre plate was initially added with $100 \mu \mathrm{l}$ of sterile broth. Then $100 \mu \mathrm{l}$ of sample was added in the first well and twofold serial dilutions of silk sample were made. At last, $20 \mu \mathrm{l}$ of bacterial/fungal cell suspension was added to each well. Microtitre plate was incubated for $24 \mathrm{~h}$ at $37 \pm 1{ }^{\circ} \mathrm{C}$ temperature for bacteria and $24-48 \mathrm{~h}$ at $28 \pm 1{ }^{\circ} \mathrm{C}$ for fungus. After incubation, $30 \mu \mathrm{l}$ of Alamer blue dye was added to each well and re-incubated for $4 \mathrm{~h}$ at room temperature.

\section{Characterization of antimicrobial compounds from bioactive fraction of spider silk Lyophilization}

The silk sample was lyophilized by first freezing at -22 $\pm 1{ }^{\circ} \mathrm{C}$ in a deep freezer for $8 \mathrm{~h}$. The frozen material was then employed for freeze drying in freeze-dryer at -40 $\pm 1{ }^{\circ} \mathrm{C}$ for $12 \mathrm{~h}$ at $0.01 \mathrm{MPa}$ pressure. This material was subsequently used for the Fourier-transform infrared spectroscopy (FT-IR), Carbon-13 nuclear magnetic resonance $\left({ }^{13} \mathrm{C} \mathrm{NMR}\right)$ \& Proton nuclear magnetic resonance $\left({ }^{1} \mathrm{H}\right.$ NMR), and $\mathrm{C}_{18}$ column reversed-phase high-performance liquid chromatography (RP-HPLC) analysis.

\section{FT-IR analysis}

The FT-IR spectrum of lyophilized silk sample was recorded on a Shimadzu FT-IR Spectrophotometer. The lyophilized silk sample was mixed with $\mathrm{KBr}$ and pellet technique was adopted to record the spectra in $\mathrm{cm}^{-1}$. The spectrum was recorded at room temperature with the resolution of $2(1 / \mathrm{cm})$ for 45 scans in the range from 4000 to $500 \mathrm{~cm}^{-1}$.

\section{${ }^{13} \mathrm{C}$ and ${ }^{1} \mathrm{H}$ NMR}

${ }^{13} \mathrm{C}$ NMR and spectrum was recorded at room temperature on Bruker AC-250 spectrometer using DMSO as solvent. The ${ }^{1} \mathrm{H}$ NMR spectrum was also recorded at room temperature on Bruker AC-250 spectrometer using $\mathrm{CDCl}_{3}$ as solvent and TMB (tetramethyl saline) as standard. 


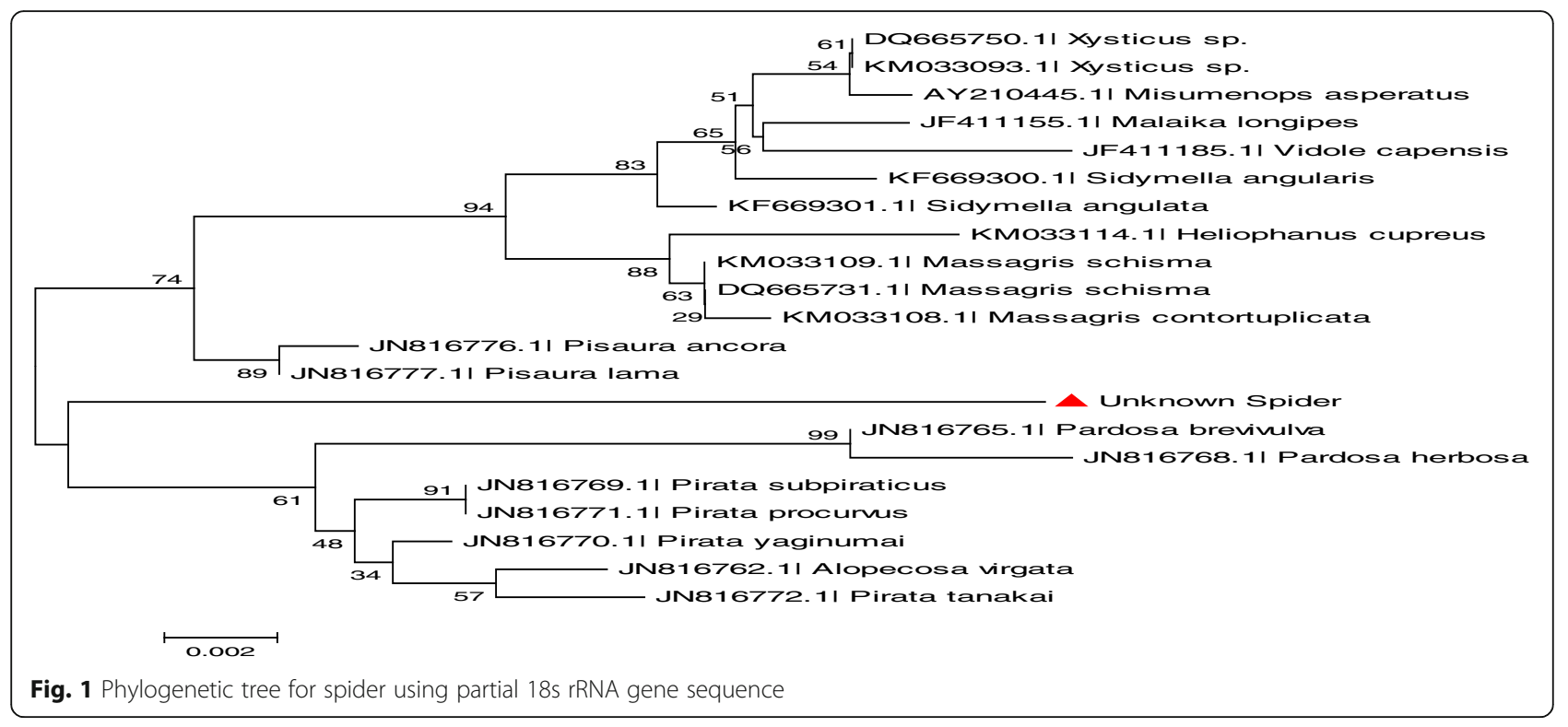

\section{$\mathrm{C}_{18}$ column RP-HPLC analysis}

The HPLC analysis of silk sample was carried out using C18 reverse phase colunm with pyridine/acetate buffer $(\mathrm{pH} 4.0)$ and 1-propanol as the organic modifier. Silkworm Sericin was used as standard.

\section{Results}

\section{Identification of spider}

\section{Morphological characteristics of spider}

Body length of spider is $6.43 \mathrm{~mm}$; cephalothorax is longer than wide measuring $3.19 \mathrm{~mm}$ in length and $2.28 \mathrm{~mm}$ in width. Cephalothorax is dark reddish brown in color with white midline band. Abdomen is longer than wide measuring $3.23 \mathrm{~mm}$ in length and $1.38 \mathrm{~mm}$ in width. The legs are brown reddish in color. The leg formula is $4,1,2,3$. The measurements of legs are as given in the Table 1. Fourth pair is longest of all leg pairs measuring $7.83 \mathrm{~mm}$ in length followed by first pair which measures about $6.32 \mathrm{~mm}$ in length. The second pair measures about $6.7 \mathrm{~mm}$ in length while third pair is smallest of all leg pairs measuring about $5.21 \mathrm{~mm}$ in length. Eyes are arranged in three rows, posterior median eye (PME) measuring about $0.25 \mathrm{~mm}$ in diameter and larger than posterior lateral eye (PLE) which was $0.10 \mathrm{~mm}$ in diameter. Anterior median eye (AME) is slightly larger than anterior lateral eye (ALE). AME is measuring about $0.12 \mathrm{~mm}$ in diameter while the diameter of ALE is $0.08 \mathrm{~mm}$ (Table 2).

The species level identification of spider was confirmed by $18 \mathrm{~S}$ rRNA gene sequencing, 931 bp partial sequence of $18 \mathrm{~S}$ rRNA gene of spider was sequenced and deposited to GenBank with accession number KY287668.1. Phylogenetic tree constructed for spider using partial $18 \mathrm{~s}$ rRNA gene sequence was given in the Fig. 1. On the basis of the position of sequence of the given spider in the phylogenetic tree, $98 \%$ similarity was found with Pardosa brevivulva. Hence, the spider was identified as Pardosa brevivulva.
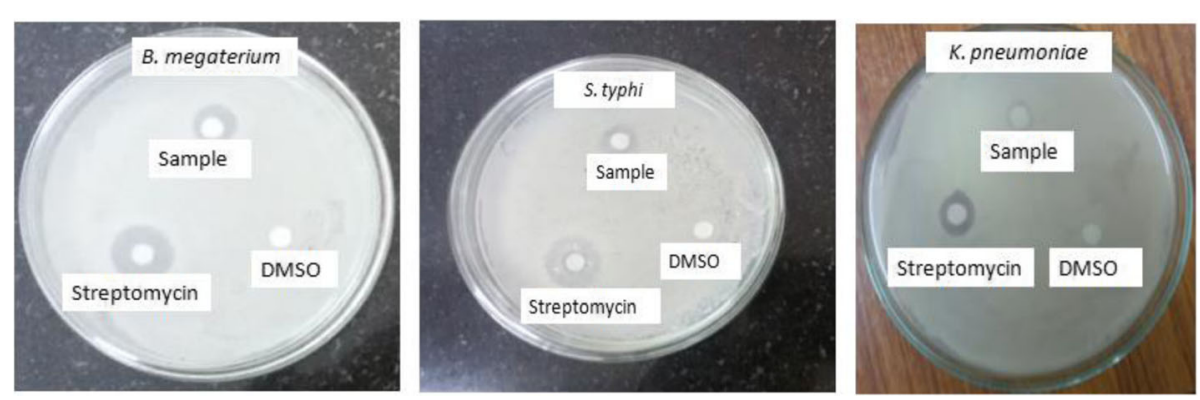

Fig. 2 Antibacterial activity of DMSO fraction of Pardosa brevivulva silk against B. megaterium, S. typhi, and K. pneumoniae 
Table 3 Antibacterial activity of DMSO fraction of Pardosa brevivulva silk

\begin{tabular}{llllll}
\hline $\begin{array}{l}\text { Sr } \\
\text { No. }\end{array}$ & $\begin{array}{l}\text { Name of the } \\
\text { bacteria }\end{array}$ & $\begin{array}{l}\text { Gram's } \\
\text { nature }\end{array}$ & \multicolumn{3}{l}{ Zone of inhibition $(\mathrm{mm})$} \\
\cline { 5 - 6 } & & Silk sample & Streptomycin & DMSO \\
\hline 1 & $\begin{array}{l}\text { B. megaterium } \\
\text { (MTCC 2444) }\end{array}$ & Gram +ve & $4.33 \pm 1.15$ & $10.00 \pm 100$ & - \\
2 & $\begin{array}{l}\text { S. typhi } \\
\text { (ATCC 23564) }\end{array}$ & Gram -ve & $5.00 \pm 1.00$ & $10.33 \pm 2.57$ & - \\
3 & $\begin{array}{l}\text { K. pneumoniae } \\
\text { (ATCC 15380) }\end{array}$ & Gram -ve & $3.33 \pm 0.57$ & $5.66 \pm 0.57$ & - \\
\hline
\end{tabular}

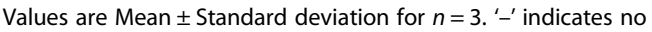
antibacterial activity

\section{Antimicrobial activity of silk Silk solubility}

The solubility of silk of $P$. brevivulva was tested separately in different solvents like chloroform, formic acid, ethanol and methanol, water, and $1 \mathrm{~N} \mathrm{HCl}$. The spider silk was totally insoluble in water, chloroform, ethanol, methanol, and $1 \mathrm{~N} \mathrm{HCl}$. Among the solubilizing agents studied, formic acid was the most suitable solvent for solubility of silk $(10 \% \mathrm{w} / \mathrm{v})$.

\section{Antimicrobial activity of silk}

The formic acid extract of silk of $P$. brevivulva was able to inhibit the growth of B. megaterium, S. typhi, and K. pneumoniae. The silk extract was also tested for its antifungal potential and it was able to inhibit the growth of Aspergillus flavus, Candida albicans, Ustilago maydis, and Alternaria solani.

\section{Antimicrobial activity of DMSO fraction of silk samples}

After membrane dialysis, the DMSO fraction of $P$. brevivulva silk was tested against B. megaterium, S. typhi, and K. pneumoniae for the confirmation of antibacterial activity (Fig. 2). The maximum zone of inhibition was recorded against $S$. typhi, followed by B. megaterium and K. pneumoniae (Table 3).

The DMSO fraction of $P$. brevivulva silk was also tested for the confirmation of its antifungal potential against $A$. flavus, C. albicans, $U$. maydis, and $A$. solani. The maximum zone of inhibition was $12.66 \pm 0.57 \mathrm{~mm}$ in diameter recorded against C. albicans, followed by $A$. flavus $(11.0 \pm 1.00 \mathrm{~mm})$, against $A$. solani (9.66 \pm $1.52 \mathrm{~mm})$ and against $U$. maydis $(9.00 \pm 1.73 \mathrm{~mm})$ (Table 4).

\section{Determination of minimum inhibitory concentration}

The minimum inhibitory concentration for $B$. megaterium and $K$. pneumoniae was $1.67 \mu \mathrm{g} / \mathrm{ml}$ and $S$. typhi was $0.83 \mu \mathrm{g} / \mathrm{ml}$. The minimum inhibitory concentration (MIC) of the P. brevivulva silk sample was also determined for C. albicans and A. flavus and it was $1.67 \mu \mathrm{g} /$ $\mathrm{ml}$ and $3.34 \mu \mathrm{g} / \mathrm{ml}$ respectively.

\section{Characterization of antimicrobial compounds from $P$. brevivulva silk \\ FT-IR analysis}

FT-IR spectrum of bioactive fraction of Pardosa brevivulva silk revealed the presence of hydroxyl group, alkyl group, alkenes group, amidic group, and sp2-hybridized $\mathrm{C}-\mathrm{H}$ bonds. The broad peak appearing at $3331.81 \mathrm{~cm}^{-1}$ is due to the presence of the intermolecular O-H.... N stretching. The peak that was observed at $1637.45 \mathrm{~cm}^{-1}$ represented the amide group. The peak at $1436.92 \mathrm{~cm}^{-1}$ indicated the presence of alkene groups $(C=C$ stretching), and the peak below $3000 \mathrm{~cm}^{-1}$ indicated the presence of alkyl group. The peaks close to $3100 \mathrm{~cm}^{-1}$ indicated the presence of sp2-hybridized $\mathrm{C}-\mathrm{H}$ bonds (Fig. 3).

\section{${ }^{13} \mathrm{C}-\mathrm{NMR}$ and ${ }^{1} \mathrm{H}-\mathrm{NMR}$ analysis}

The ${ }^{13} \mathrm{C}$-NMR of bioactive fraction of Pardosa brevivulva silk revealed that the peak at $12.49 \delta \mathrm{ppm}$ was assigned to $\mathrm{CH}_{3}$ group. The peak at $26.32 \delta$ ppm was the characteristic peak for $\mathrm{CH}_{2}-\mathrm{C}$. The peak appearing at $53.90 \delta \mathrm{ppm}$ indicated the presence of $\mathrm{CH}-\mathrm{N}$ group. The presence of $\mathrm{RCH}_{2} \mathrm{O}$ group was observed by peak at $67.72 \delta \mathrm{ppm}$. The peak at $81.54 \delta \mathrm{ppm}$ was for sp2-hybridized carbon ( $\mathrm{C}=\mathrm{C}$ group). Similarly, the peak at $164.03 \delta \mathrm{ppm}$ indicated the presence of amidic carbonyl group (Fig. 4).

${ }^{1} \mathrm{H}-\mathrm{NMR}$ spectrum of bioactive fraction of Pardosa brevivulva silk revealed that the intense peak in the

Table 4 Antifungal activity of DMSO fraction of spider silk

\begin{tabular}{|c|c|c|c|c|}
\hline \multirow{2}{*}{$\begin{array}{l}\text { Sr } \\
\text { No. }\end{array}$} & \multirow[t]{2}{*}{ Name of the fungi } & \multicolumn{3}{|c|}{ Zone of inhibition (mm) } \\
\hline & & Silk sample & Nystatin $(50 \mu \mathrm{g} / \mathrm{ml})$ & DMSO \\
\hline 1 & $\begin{array}{l}\text { Aspergillus flavus } \\
\text { (MTCC 873) }\end{array}$ & $11.0 \pm 1.00$ & $12.33 \pm 0.57$ & - \\
\hline 2 & Candida albicans (MTCC 227) & $12.66 \pm 0.57$ & $14.33 \pm 0.57$ & - \\
\hline 3 & $\begin{array}{l}\text { Ustilago maydis } \\
\text { (MCIM 983) }\end{array}$ & $9.00 \pm 1.73$ & $11.33 \pm 0.57$ & - \\
\hline 4 & $\begin{array}{l}\text { Alternaria solani } \\
\text { (MCIM 887) }\end{array}$ & $9.66 \pm 1.52$ & $11.00 \pm 1.00$ & - \\
\hline
\end{tabular}

Values are Mean \pm Standard deviation for ' $n '=3$. ' - ' indicates no antifungal activity 


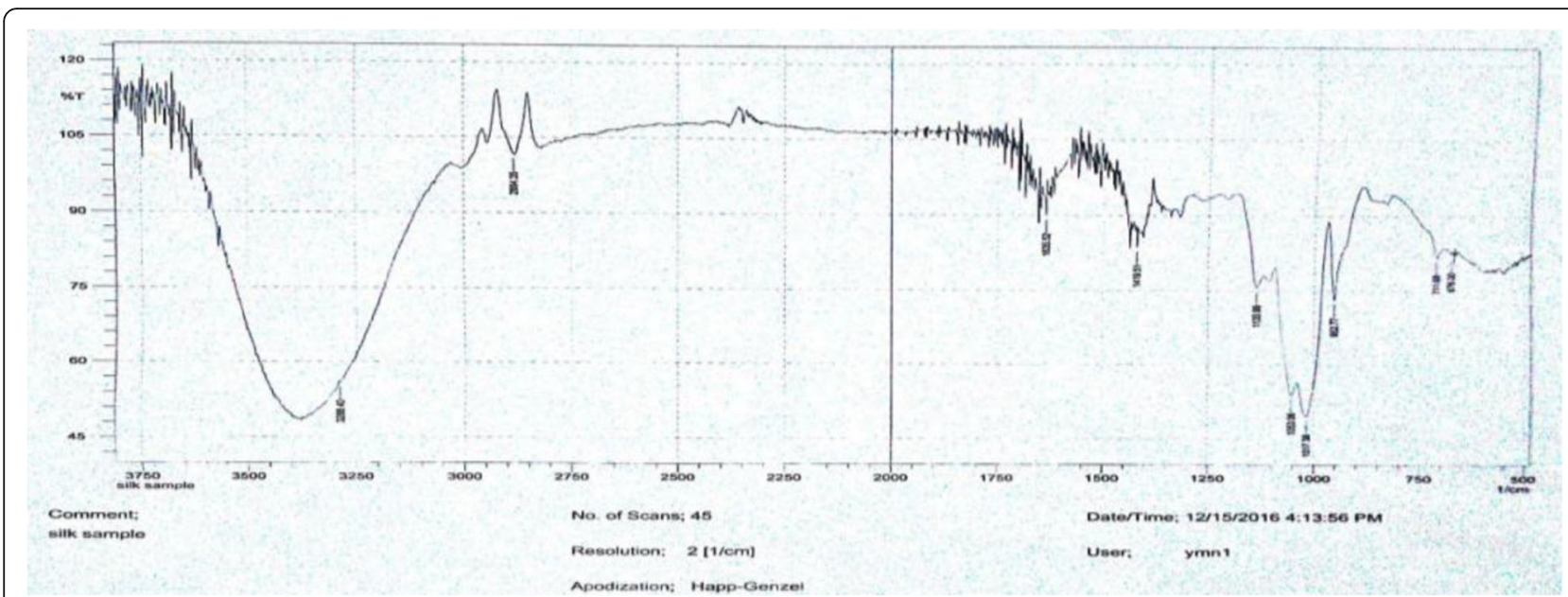

Fig. 3 FT-IR spectrum of bioactive fraction of Pardosa brevivulva silk

range of 2.3 to $2.5 \delta \mathrm{ppm}$ was assigned to alkyl group $\left(\mathrm{CH}_{3}\right)$. The peaks at 3.0 to $3.8 \delta \mathrm{ppm}$ were the characteristic peaks for $\mathrm{NH}$ group. The spectrum showed the peaks between 4.4 to $4.8 \delta \mathrm{ppm}$ for $\mathrm{OH}$ group and the peak at $5.1 \delta \mathrm{ppm}$ for venyl group $(\mathrm{C}=\mathrm{CH})$ (Fig. 5).

\section{$C_{18}$ column RP-HPLC analysis}

RP-HPLC chromatogram of bioactive fraction of Pardosa brevivulva silk sample was carried out (Fig. 6). Silkworm Sericin was used as standard (Fig. 7). The retention times of peaks of silk sample at 3.371 and $8.720 \mathrm{~min}$ were very close to the retention times of the Silkworm Sericin, i.e., 3.378 and $8.688 \mathrm{~min}$.

\section{Discussion}

Pardosa brevivulva Tanaka, 1975 is the species of wolf spiders commonly distributed in Russia, China, Korea, and Japan (World Spider Catalog, 2017). We are reporting Pardosa brevivulva Tanaka, 1975 for the first time in the mango and soybean fields of Latur district (M.S.), India. In the present investigation, the silk of Pardosa brevivulva was tested for antimicrobial activity. Solubilization is one of the most difficulties in the study of structural proteins like silk, collagen, elastin, resilin, and keratin (Lucas, Shaw, \& Smith, 1955). Lombari and Kaplan (1993) encountered considerable difficulty in attempting to solubilize and purify natural spider silk while retaining the molecular weight integrity of the fiber. In the current study, different solvents were used to confirm the solubility of the natural silk of spider species. Among different solvents, formic acid was the most suitable and optimum for antimicrobial activity. The solubility of spider silk in formic acid was also reported by Hsia, Gnesa, Jeffery, Tang, and Craig (2011), Sebastian and Peter (2009), and Slotta, Mougin, Romer, and Leimer (2012). The silk extract of Pardosa brevivulva in

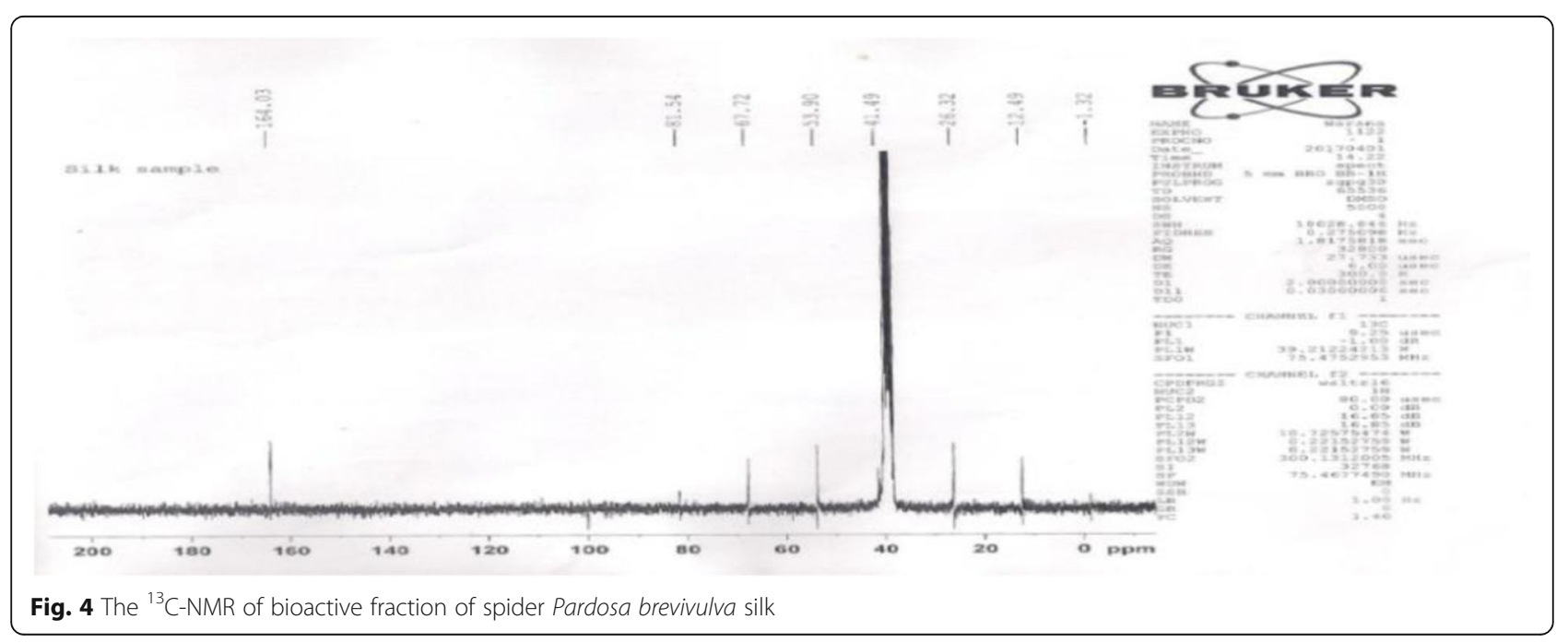




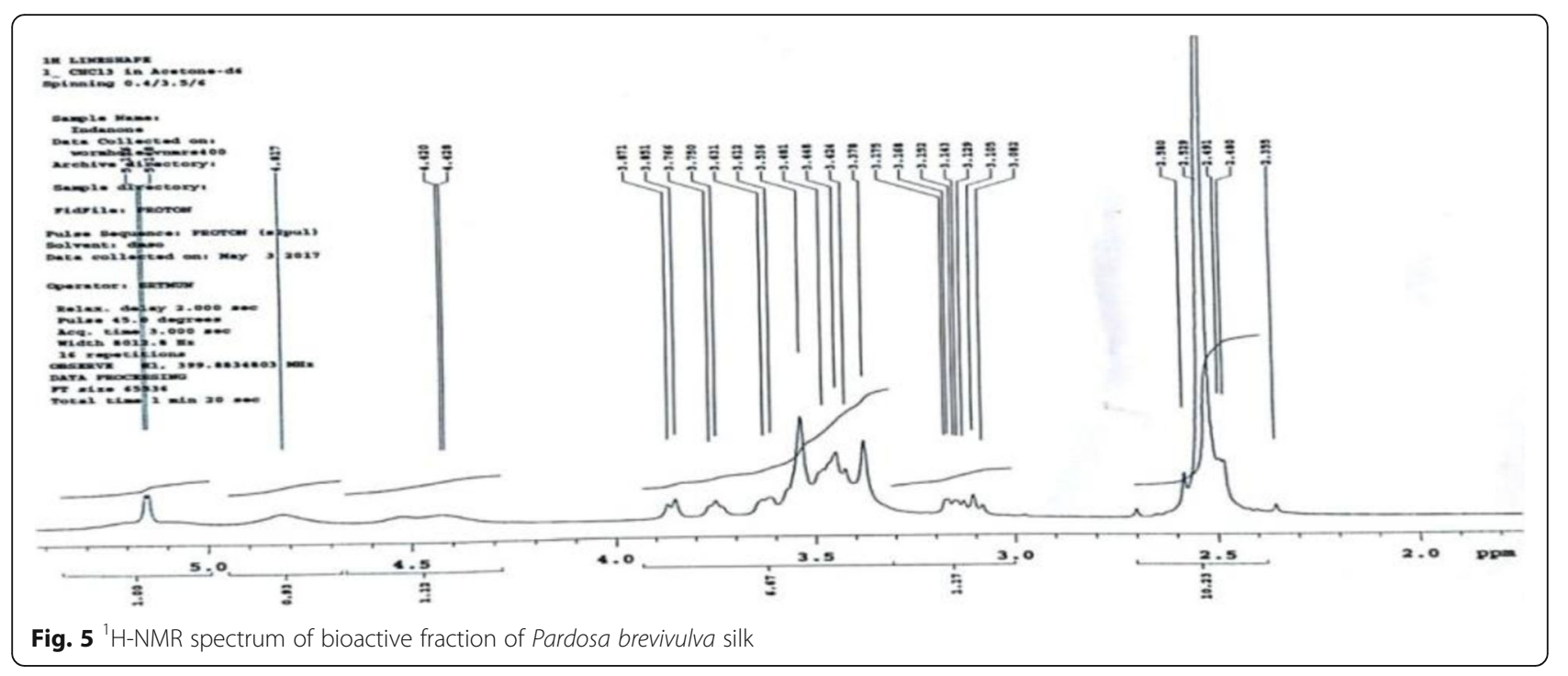

formic acid $(10 \% w / v)$ showed both antibacterial as well as antifungal activity.

The spider silk extract in formic acid was employed for membrane dialysis and re-dissolved in in dimethyl sulfoxide (DMSO). The study revealed that DMSO fraction of Pardosa brevivulva silk was able to inhibit the growth of gram-positive $B$. megaterium and two gram-negative bacteria $S$. typhi and $K$. pneumoniae. The activity of spider silk showed a dose-dependent response, with increasing concentration of silk the activity was increased. Roozbahani, Asmar, Ghaemi, and Issazadeh (2014) tested the silk of Pholcus phalangioides against two bacterial foodborne pathogens viz. Listeria monocytogenes and Escherichia coli and reported the greater inhibitory effect on gram-positive bacteria $L$. monocytogenes than gram-negative bacteria E. coli. Mirghani, Kabbashi, Elfaki, and Zulkifli (2012) tested spider silk against two bacteria viz. B. subtilis and E. coli and found that the silk showed higher inhibition zone against gram-positive bacteria (B. subtilis) compared to gram-negative bacteria (E. coli). Similarly,
Amaley, Gawali, and Akarte (2014) checked the antibacterial potential of silk of Nephila pilipes and reported that the silk has ability to inhibit the growth of Escherichia coli, Staphylococcus aureus, and Pseudomonas aeruginosa. Wright and Goodacre (2012) tested the silk of Tegenaria domestica against gram-positive bacterium Bacillus subtilis and gram-negative bacterium $E$. coli and observed that the silk is effective against a gram-positive bacteria (B. subtilis) but not against gram-negative bacteria $(E$. coli). The protein nature of the antimicrobial compounds had been confirmed by the treatment of proteinase $\mathrm{k}$ which significantly reduced the activity of silk. Gomes, Leonor, Mano, Reis, and Kaplan (2011) assessed for antimicrobial activity of genetically engineered spider silk against gram-negative Escherichia coli and gram-positive Staphylococcus aureus and reported prominent activity against E. coli as compared to S. aureus. Al-Kalifawi and Kadem (2017) reported the antimicrobial activity of Tegenaria domestica silk against both gram-negative and gram-positive bacteria.

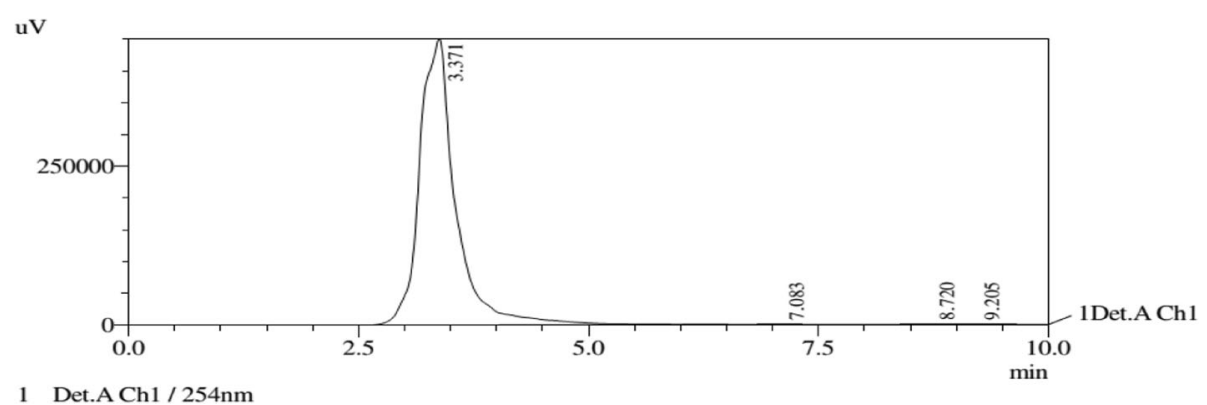

Fig. 6 RP-HPLC chromatogram of bioactive fraction of Pardosa brevivulva silk sample 


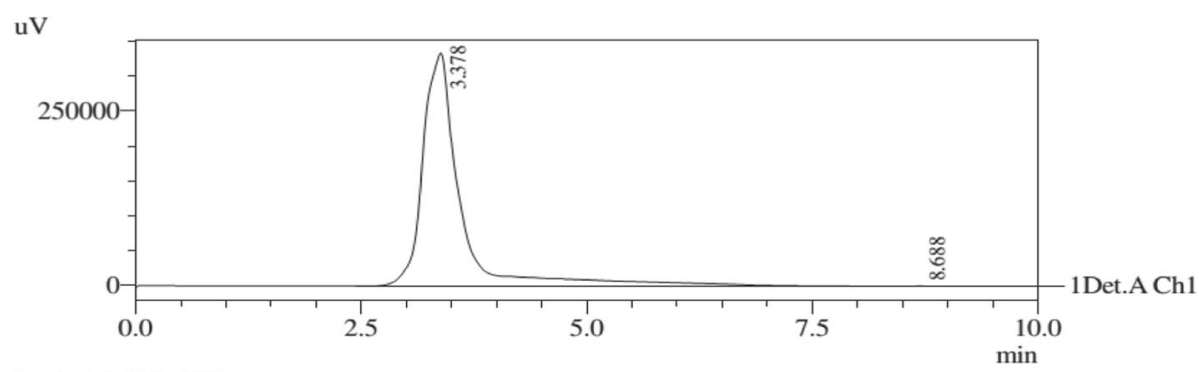

1 Det.A Ch1 / 254nm

Fig. 7 RP-HPLC chromatogram of the Silkworm Sericin sample

P. brevivulva silk showed activity against Aspergillus flavus, Candida albicans, Ustilago maydis, and Alternaria solani. The findings of Wright and Goodacre (2012) does not match with our findings who tested silk of $T$. domestica against two species of fungi, S. cerevisiae and $A$. niger and reported that silk does not inhibit the growth on fungi.

The bioactive fraction of $P$. brevivulva silk was employed for characterization of antimicrobial compounds by FT-IR analysis, ${ }^{13} \mathrm{C}-\mathrm{NMR} \&{ }^{1} \mathrm{H}-\mathrm{NMR}$ analysis, and $\mathrm{C}_{18}$ colunm RP-HPLC analysis. FT-IR spectrum of DMSO fraction of Pardosa brevivulva silk revealed the presence of hydroxyl group, alkyl group, alkenes group, amidic group, and sp2-hybridized $\mathrm{C}-\mathrm{H}$ bonds. Divya, Srinivasan, and Manohari (2016) reported the presence of amine, alkanes, hydroxyl, nitriles, alkyne, aromatic, alcohol, and ester in the silk extracts of sericin which is indicated by FT-IR analysis that might be responsible for the present antibacterial activity. Further, the $\mathrm{C}_{18}$ column RP-HPLC analysis of the silk sample showed the peaks at the retention times very close to the retention times of the standard protein Silkworm Sericin.

Riechert and Lockley (1984) report that a spider may kill as many as 50 times the number of prey it consumes. Spiders have the ability to preserve its extra food for months and even years by folding it in silk fibers (Tahir, Khanum, Zaheer, \& Samiullah, 2017). This stored food is safe from attack of fungus or other microbes (Eberhard, Barrantes, \& Weng, 2006). The spider silk is used in prey wrapping and this silk being antimicrobial would benefit the spider as the prey would be less likely to contain microbes (Wright \& Goodacre, 2012). Spider gains the benefits of antimicrobial compounds present in the silk by preserving its prey for longer durations (Roozbahani et al., 2014).

\section{Conclusion}

It can be concluded from the present investigation that the Pardosa brevivulva silk has good antimicrobial potential with useful bactericidal and fungicidal properties and it is the first report of this spider from India.

\begin{abstract}
Abbreviations
${ }^{13} \mathrm{C}$ NMR: Carbon-13 nuclear magnetic resonance; ${ }^{1} \mathrm{H}$ NMR: Proton nuclear magnetic resonance; ALE: Anterior lateral eye; AME: Anterior median eye; BLASTn: Nucleotide Basic Local Alignment Search Tool; DMSO: Dimethyl sulfoxide; FT-IR: Fourier-transform infrared spectroscopy; PCR: Polymerase chain reaction; PLE: Posterior lateral eye; PME: Posterior median eye; RPHPLC: Reversed-phase high-performance liquid chromatography
\end{abstract}

\section{Acknowledgements}

Authors are also thankful to Prof. P. K. Zubaidha, School of Chemical Sciences, SRTM University, Nanded for her help in NMR analysis and Prof. P. A. Kulkarni, Department of Chemistry, Yeshwant College, Nanded for his help in FT-IR analysis.

\section{Funding}

This work is financially supported by the Department of Science and Technology (DST), New Delhi under the scheme DST INSPIRE Fellowship to Mr. N. N. Phartale.

\section{Availability of data and materials}

The dataset(s) supporting the conclusions of this article is (are) included within the article (and its additional file(s)). Data sharing not applicable to this article as no datasets were generated or analyzed during the current study on this species. The conclusions are based on the data generated from the current study.

\section{Authors' contributions}

NN carried out the experiments, statistical analysis, and drafted the manuscript. HJ and MA participated in the design of the study and assisted in antimicrobial activity. TA was involved in design of the study and preparation of the manuscript. GG was involved in conception, design, and coordination of the study. All authors read and approved the final manuscript.

\section{Ethics approval and consent to participate}

No human samples were used. Not applicable as the study relates to use of spider silk of this species only.

\section{Consent for publication}

Not applicable.

Competing interests

The authors declare that they have no competing interests.

\section{Publisher's Note}

Springer Nature remains neutral with regard to jurisdictional claims in published maps and institutional affiliations. 
Received: 1 July 2018 Accepted: 8 April 2019

Published online: 07 May 2019

\section{References}

Agnarsson, I., Kuntner, M., \& Blackledge, T. A. (2010). Bioprospecting finds the toughest biological material: Extraordinary silk from a giant riverine orb spider. PLoS One, 5, e11234.

Al-Kalifawi, E. J., \& Kadem, Y. J. (2017). The antimicrobial activity of Al-Ankabut's home (Spider's web) extract. Mesopotamia Environmental Journal, Special Issue C, 54-63.

Amaley, A., Gawali, A. A., \& Akarte, S. R. (2014). Antibacterial nature of dragline silk of Nephila pilipes (Fabricius, 1793). Indian Journal of Arachnology, 3(1), 8-11.

Andersen, S. O. (1970). Amino acid composition of spider silks. Comparative Biochemistry and Physiology, 35, 705-711.

Bradford, M. M. (1976). A rapid and sensitive method for the quantification of microgram quantities of protein utilizing the principle of protein-dye binding. Analytical Biochemistry, 72, 248-254.

Coddington, J. A., Griswold, C. E., Silva, D., Penaranda, D., \& Larcher, S. (1991). Designing and testing sampling protocols to estimate biodiversity in tropical ecosystems. In E. C. Dudley (Ed.), The unity of evolutionary biology: Proceedings of the fourth international congress of systematic and evolutionary biology, (pp. 44-60). Portland: Dioscorides Press.

Divya, J., Srinivasan, J., \& Manohari, B. G. (2016). FT-IR analysis and anti bacterial activity of silk sericin. International Journal of Pharma and Bio Sciences, 7(3), 113-119.

Eberhard, W. G., Barrantes, G., \& Weng, J. L. (2006). Tie them up tight: Wrapping by Philoponella vicina spiders breaks, compresses and sometimes kills their prey. Naturwissenschaften, 93, 251-254.

Gomes, S. C., Leonor, I. B., Mano, J. F., Reis, R. L., \& Kaplan, D. L. (2011). Antimicrobial functionalized genetically engineered spider silk. Biomaterials, 32(18), 4255-4266.

Hsia, Y., Gnesa, E., Jeffery, F., Tang, S., \& Vierra, C. (2011). Spider silk composites and applications. Metal, ceramic and polymeric composites for various uses. InTech, Rijeka, 488.

Keswani, S., Hadole, P., \& Rajoria, A. (2012). Checklist of spiders (Arachnida: Araneae) from India-2012. Indian Journal of Arachnology, 1, 1-129.

Lombardi, S.J. and Kaplan, D.L. (1990). The amino acid composition of major ampullate gland silk (dragline) of Nephila clavipes (Araneae, Tetragnathidae). Journal of Arachnology, 297-306.

Lombari, S. J., \& Kaplan, D. L. (1993). The United States of America as represented by the Secretary of the Army, method to achieve solubilization of spider silk proteins. U.S. Patent 5,245,012.

Lucas, F., Shaw, J. T. B., \& Smith, S. G. (1955). The chemical constituents of some silk fibroins andits bearing on their physical properties. Journal of the Textile Institute, 46, 440-444.

Mcheidze, T. S. (1997). Spiders of Georgia: systematics, ecology, zoogeographic review. Tbilisi Univ, 390.

Mirghani, M. E. S., Kabbashi, N. A., Elfaki, F. A., \& Zulkifli, M. Z. F. B. (2012). Investigation of the spider web for antibacterial activity. In Malaysian international conference on trends in bioprocess engineering (MICOTriBE). BT-201-5.

Phartale, N. N., Kadam, J. A., \& Gyananath, G. (2016). First report of Geolycosa charitonovi (Mcheidze, 1997) (Araneae: Lycosidae) from India. Journal of Entomology and Zoology Studies, 4(5), 937-939.

Rampersad, S. N. (2012). Multiple applications of Alamar blue as an indicator of metabolic function and cellular health in cell viability bioassays. Sensors, 12 $12347-12360$.

Riechert, S. E., \& Lockley, T. (1984). Spiders as biological control agents. Annual Review of Entomology, 29, 299-320.

Roozbahani, H., Asmar, M., Ghaemi, N., \& Issazadeh, K. Z. (2014). Evaluation of antimicrobial activity of spider silk Pholcus phalangioides against two bacterial pathogens in food borne. International Journal of Advanced Biological and Biomedical Research, 2(7), 2197-2199.

Saravanan, D. (2006). Spider silk-structure, properties and spinning. JTATM, 5(1), 1-20.

Sebastian, P. A., \& Peter, K. V. (2009). Spiders of India, first edition. Hyderabad: Universities Press.

Slotta, U., Mougin, N., Romer, L., \& Leimer, A. H. (2012). Synthetic spider silk proteins and threads. Society for Biological Engineering, 108, 43-49.

Tahir, H. M., Khanum, Z. K., Zaheer, A., \& Samiullah, K. (2017). Spider silk: An excellent biomaterial for medical science and industry. Punjab University Journal of Zoology, 32(1), 143-154.
Tanaka, H. (1975). A new species of the genus Pardosa from Japan (Araneae: Lycosidae). Bulletin of the Biogeographical Society of Japan, 31, 21-24.

Toti, D. S., Coyle, F. A., \& Miller, J. A. (2000). A structured inventory of Appalachian grass bald and heath bald spider assemblages and a test of species richness estimator performance. Journal of Arachnology, 28, 329-345.

World Spider Catalog. (2017). Natural history museum Bern. online at http://wsc. nmbe.ch, version 18.5, accessed on 16 Nov 2017. doi: 10.24436/2

Wright, S., \& Goodacre, S. L. (2012). Evidence for antimicrobial activity associated with common house spider silk. BMC Research Notes, 5, 326.

Yajko, D. M., Madej, J. J., Lancaster, M. V., Sanders, C. A., Cawthon, V. L., Gee, B., Hadley, W. K. (1995). Colorimetric method for determining MICs of antimicrobial agents for Mycobacterium tuberculosis. Journal of Clinical Microbiology, 33(9), 2324-2327.

\section{Submit your manuscript to a SpringerOpen ${ }^{\circ}$ journal and benefit from:}

- Convenient online submission

- Rigorous peer review

- Open access: articles freely available online

High visibility within the field

- Retaining the copyright to your article

Submit your next manuscript at $\boldsymbol{\nabla}$ springeropen.com 